4 Andrew W. Slack ${ }^{1 *}$, Nickolas E. Zeibig-Kichas ${ }^{1}$, Jeffrey M. Kane ${ }^{1}$, and J. Morgan Varner $^{2}$ 5

\section{Contingent resistance in longleaf pine (Pinus palustris) growth and defense 10 years}

\section{following smoldering fires}

\author{
Andrew W. Slack, , Nickolas E. Zeibig-Kichas , Jeffrey M. Kane', and J. Morgan Varner
} (1)

${ }^{1}$ Department of Forestry and Wildland Resources, Humboldt State University, 1 Harpst Street, Arcata, CA, 95521, USA.

${ }^{2}$ Department of Forest Resources \& Environmental Conservation, Virginia Tech, 310 West

Campus Drive (MC 0324), Blacksburg, VA 24061 USA.

*corresponding author: aslack@humboldt.edu

11

Suggested Running Head: Longleaf pine resistance to smoldering duff fire

\section{Abstract}

15

In many fire-prone woodlands and forests, fire exclusion has resulted in substantial litter and duff accumulations capable of long-duration smoldering once fire is reintroduced. While previous research has shown that the soil heating from smoldering fires resulted in short-term reductions in coarse root non-structural carbohydrates and latewood growth, information on the long-term effects of smoldering fire is lacking. Our study compared the effects of three smoldering fire treatments (root only, stem only, root and stem) and two control treatments (no fire and surface fire only) on longleaf pine (Pinus palustris) growth and defense ten years after treatments. We cored 17 to 29 similar sized trees per treatment and measured growth as basal area increment and defense as resin duct properties (e.g., resin duct size, \% resin duct area). We 
24 used generalized linear mixed models to determine the influence of smoldering treatments and

25 climate on basal area increment and resin duct properties. Variation in basal area increment and

26 resin duct size during the previous ten years were positively correlated with the subsequent ten

27 years, $r^{2}=0.71$ and $r^{2}=0.65$, respectively. Additionally, temporal variation in growth and

28 defense were related to climatic factors. Growth had the strongest correlation with current

29 August temperatures $(r=-0.50)$, and defense had the strongest correlation with current

30 December temperatures $(r=-0.64)$. Basal area increment was best predicted by summer and fall

31 Palmer Drought Severity Index, while resin duct size was best predicted by the interaction of

32 treatment and precipitation during the previous November. During the three driest years

33 following treatment smoldering duration had a negative relationship with basal area increment $(p$

$\left.34<0.0085 ; r^{2}=0.08\right)$ and resin duct size $\left(p<0.0003 ; r^{2}=0.16\right)$. While longleaf pine growth was

35 generally resistant to long-duration soil heating following years of fire exclusion, the proceeding

36 growth response was contingent on the post-fire climate. Longleaf pine resin duct size was

37 sensitive to the effects of smoldering fire, and potential negative impacts may be exacerbated by

38 lower precipitation. Restoring fire to long-unburned sites proceeded by warmer and drier climate

39 conditions may result in reduced longleaf pine growth and defense that may contribute to

40 increased probability of mortality during subsequent disturbances.

42 Keywords: Drought, duff, prescribed fire, resin ducts, restoration, tree rings

\section{1. Introduction}

Declines in fire frequency in many forest and woodland ecosystems have led to numerous 46 structural changes, including increased tree density and altered species composition, favoring 
47 more shade-tolerant species and less shade-intolerant, fire-dependent species (Agee 1996,

48 Gilliam and Platt 1999, Keane et al. 2002). In many ecosystems, fire exclusion also results in

49 deep ground fuel accumulations, including fermentation and humus layers collectively termed

50 "duff", that are prone to long-duration smoldering when ignited (Varner et al. 2005). These

51 changes in forest and fuel structure have been attributed to altered fire behavior and elevated tree

52 mortality in many forests and woodlands, prompting the need for fuels treatments to mitigate the

53 impacts of fire exclusion (Agee and Skinner 2005, Ryan et al. 2013).

Prescribed fire is used as a restoration tool in many fire-dependent ecosystems across the

55 United States to reestablish historical fire regimes (Brown et al. 2004, Ryan et al. 2013), but after

56 prolonged exclusion the reintroduction of fire can injure trees, leading to unintended mortality

57 (Swezy and Agee 1991, Stephens and Finney 2002, Varner et al. 2007). Increased tree mortality

58 following the reintroduction of fire has been attributed to fine root consumption and thermal

59 girdling as a result of the prolonged heating associated with smoldering fires, and is exacerbated

60 by the substantial basal accumulation of duff around trees (Ryan and Frandsen 1991, Varner et

61 al. 2009, O'Brien et al. 2010). Prolonged heating and loss of roots may also contribute to delayed

62 tree mortality by reducing tree vigor and predisposing trees to drought or biological agents, such

63 as insects and pathogens (Swezy and Agee 1991). Previous studies have shown that increased

64 allocation to growth and defense are associated with decreased probability of tree mortality from

65 factors such as competitive stress and bark beetles (Das et al. 2007, Kane and Kolb 2010,

66 Ferrenberg et al. 2014). However, the longer-term influence of smoldering fire on tree vigor and

67 health is not well understood.

Although tree vigor may be influenced by smoldering duff fires, other factors may

69 contribute to the variation in growth and defense within and among trees. For instance, tree vigor 
may be related to previous growth and defense, where trees that had faster growth and greater

71 defense in the past are suspected to have faster growth and greater defense in subsequent years.

72 Climate is also an important factor known to influence tree growth (Meldahl et al. 1999,

73 Henderson and Grissino-Mayer 2009) and defense (Rigling et al. 2003, Hood et al. 2015).

74 Research that considers these multiple factors and their relationship with growth and defense will

75 broaden our understanding of tree vigor dynamics under alternative land management practices

76 and a shifting climate.

Information on how restoration treatments affect tree vigor in reference to subsequent

78 disturbances (e.g., drought, wildfire) is of increasing interest to scientists and natural resource

79 managers (Millar et al. 2007, D’Amato et al. 2013, Thomas and Waring 2014). There are

80 concerns that restoration efforts may predispose trees to future mortality, especially when

81 considering the complex interactions of tree vigor, climate, and disturbance regimes. For

82 instance, recent research by Nesmith et al. (2015) found that pre-fire vigor, defined by radial

83 growth rate, had a considerable influence on post-fire mortality for sugar pine (Pinus

84 lambertiana) in Sequoia National Park, California. Additionally, van Mantgem et al. (2013)

85 found that a pervasively warming climate can exacerbate tree stress and may contribute to

86 increased mortality following fire and other disturbance events. One way to assess tree vigor

87 following disturbance is through the concepts of ecological resilience. While resilience has been

88 defined in multiple ways (Holling 1973, Gunderson 2000), methods describing tree resistance

89 and resilience can reveal how a particular disturbance and the interaction with intrinsic (e.g.,

90 genetics and physiological characteristics) and extrinsic (e.g., competition and climate) factors

91 influences tree vigor over time. Resilience in tree vigor can be defined as the ability of a tree to

92 return to pre-disturbance performance levels, while resistance in tree vigor refers to the ability of 
93 a tree to withstand negative impacts of a disturbance (Webster et al. 1975, Lloret et al. 2011).

94 Understanding these concepts, and the broader intrinsic and extrinsic variables that influence

95 resistance and resilience, will help inform appropriate management decisions. This is particularly

96 important in a warming climate, which will likely lead to increased tree stress and a reduced

97 capacity for trees to resist and/or recover from disturbance.

Longleaf pine ( $P$. palustris) is an ecologically important tree species in the southeastern

99 United States and a model species for studying the effects of smoldering fire behavior on growth

100 and defense after years of fire exclusion (Varner et al. 2005). Longleaf pine ecosystems have

101 been reduced to less than 2 million ha (Frost 2006), and managers across the region are

102 implementing considerable restoration efforts. Fire is a vital component of longleaf pine

103 ecosystems with numerous species adapted to persist in frequent, low severity fire regimes that

104 were historically more common (Platt 1999). However, fire exclusion in the southeastern U.S.

105 has dramatically reduced fire, leading to reductions in biodiversity and alterations to fundamental

106 ecosystem processes (Noss et al. 1995, Van Lear et al. 2005, Varner et al. 2005). There is

107 increased interest by managers to reintroduce fire to longleaf pine ecosystems, however, there is

108 substantial concern that the reintroduction of prescribed fire after years of fire exclusion could

109 lead to unintended tree mortality (Varner et al. 2005, 2007, O’Brien et al. 2010). Previous work

110 on longleaf pine has attributed basal duff accumulations associated with fire exclusion with

111 increased duration of lethal soil heating $\left(>60^{\circ} \mathrm{C}\right)$. Prolonged smoldering and heating of the

112 mineral soil was linked to reductions in coarse root carbohydrate concentrations that may lead to

113 longer term declines in longleaf pine vigor (Varner et al. 2009).

114 The primary objective of this study was to assess the longer term impacts of smoldering

115 and other factors affecting longleaf pine vigor following the reintroduction of fire. To better 
116 inform which factors were important covariates we examined: 1) the within-tree relationships

117 between previous and subsequent growth and defense; and 2) the influence of climate variables

118 on measures of longleaf pine growth and defense. We then analyzed: 3) the relative importance

119 of treatment and climate on longleaf pine growth and defense; and 4) the relationship between

120 smoldering duration and growth and defense in the years following treatment. It is important to

121 note that this study was concerned with smoldering fire specifically and did not account for the

122 full range of fire effects that contribute to tree damage and may additionally influence tree

123 growth and defense. However, our results provide important insights into the potential impacts of

124 prescribed fire restoration treatments on the long-term growth and defense of longleaf pine

125 following decades of fire exclusion.

126

127 2. Methods

$128 \quad 2.1$ Study site

129 This study was conducted at the Ordway-Swisher Biological Station near Melrose,

130 Florida (Figure 1, Putnam County, N29840 / W81874) in a stand dominated by longleaf pine

131 with a dense midstory consisting of oak species (Quercus laevis, Q. geminata, and $Q$.

132 hemisphaerica). The area had not burned in 37 years prior to the implementation of experimental

133 treatments, resulting in a dense overstory and deep litter and duff layers (up to $15 \mathrm{~cm}$ ) on the

134 forest floor (Varner et al. 2009). For reference, observational and fire-scar data suggest that

135 many longleaf pine ecosystems historically burned as frequently as every two to three years

136 (Frost 2006, Stambaugh et al. 2011), thus this site has missed between 12 and 18 fire events.

137 Soils of the site are deep, well-drained Candler series Lamellic Quartzipsamments (Readle

138 1990). The site has gentle $(<5 \%)$, north-facing slopes averaging $36 \mathrm{~m}$ above mean sea level. The 
139 climate of the area is characterized by long, warm and humid summers and short, mild winters.

140 Climate for the study site was slightly warmer and drier during the ten years following treatment

141 (2004-2013) than the ten years preceding treatment (1995-2003) with a mean annual temperature

142 of $20.7^{\circ} \mathrm{C}$ and a mean annual precipitation of $1192 \mathrm{~mm}$ (NCDC 2014).

\subsection{Experimental design}

Experimental treatments were established in the fall of 2003 as part of a previous study examining the short-term (one year) impacts of duff smoldering on longleaf pine radial growth and root non-structural carbohydrates (Varner et al. 2009). The experiment included five treatments across 116 randomly selected trees, ranging from 30 to $40 \mathrm{~cm}$ in diameter at breast height $(\mathrm{DBH}$; breast height $=1.37 \mathrm{~m})$, with 20 replicates per treatment, except for the no fire control which had 36 replicates. The burn treatments were designed to expose specific areas of

151 the pines to heating injury, including the root system (root burn), stem of the tree (stem burn), a 152 combined root and stem burn (root and stem burn), surface fire only, and a no fire control. In the root treatments, litter and debris accumulations were gently removed 5-10 cm away from the

154 base of the tree stem to create an effective buffer against basal heating on the stem while 155 simultaneously minimizing disruption of accumulated materials on the forest floor (Varner et al. 156 2009). In the stem treatments, fire was isolated to a $20 \mathrm{~cm}$ radius directly around each tree base 157 by shielding the adjacent forest floor and underlying root system with a $10 \mathrm{~cm}$ tall aluminum 158 barrier encased in fire shelter material (Cleveland Laminating Corp., Cleveland, OH, USA). The 159 bases of these barriers were buried to a depth of around $2 \mathrm{~cm}$ in the surface mineral soil. The root and stem treatment was facilitated by burning the entire $1 \mathrm{~m}$ radius without any protection, thus

161 heating the stem base and root system simultaneously. Trees in the surface fire treatment were 
162 burned but immediately extinguished with a flapper at the conclusion of flaming combustion,

163 effectively prohibiting duff smoldering. To ensure combustion had fully ended, water was used

164 as needed on the surface fire trees if smoldering persisted. The final treatment included unburned

165 trees that were randomly assigned to the no fire control treatment. Fire temperatures were

166 recorded using Type $\mathrm{J}$ thermocouples (range $0-1200^{\circ} \mathrm{C}$; Omega Laboratories, Stamford, CT,

167 USA) on a subset of trees from all treatments. Residual smoldering time was also recorded in

168 seconds using a stopwatch on a subset of 71 trees. Details of the treatments and corresponding

169 fire behavior (including stem, duff, and soil heating profiles) and post-fire tree measures are

170 reported elsewhere (Varner et al. 2009).

171

$172 \quad 2.3$ Growth and defense measures

173 In November 2013, ten years following the burning treatments, all subject trees were

174 cored once along the bole ( $c a .30 \mathrm{~cm}$ above the base) of the tree using a large diameter (12 $\mathrm{mm})$

175 increment borer. Some of the sampled trees had rot within the wood and we were not able to

176 extract a viable core. This reduced the final sample size within each treatment: no fire control (n

$177=36)$, surface fire control $(n=20)$, root burn $(n=18)$, root and stem burn $(n=17)$, stem burn ( $n$

$178=17)$.

179 Extracted tree cores were processed and measured using standard dendrochronology

180 methods. Cores were mounted and progressively sanded with 80- to 600-grit sandpaper on a belt

181 sander then scanned to produce a high-resolution image (1,200 dpi) for each core. These images

182 were processed in WinDendro (Regent Instruments 2014), annual ring boundaries for each core

183 were visually identified and total ring width $\left(\mathrm{mm} \mathrm{y}^{-1}\right)$ was measured. Tree ring measurements for

184 all subject trees were subsequently analyzed in COFECHA to determine correlations between 
185 ring patterns to help assess crossdating accuracy (Grissino-Mayer 2001). All samples were

186 successfully crossdated against the master chronology with an overall mean sensitivity of 0.303

187 and a series intercorrelation of 0.473 . The master chronology was constructed by averaging the

188 individual tree chronologies together for all 108 cores, since a site- or region-specific master

189 chronology was not available.

190 Growth was measured as basal area increment (BAI, $\left.\mathrm{cm}^{2} \mathrm{y}^{-1}\right)$, and was calculated for 191 each tree using DBH, bark thickness, and annual ring widths. Bark thickness was estimated using 192 an equation specific to longleaf pine based on DBH (Lutes 2013). The computation of BAI 193 assumed that ring width was constant within each annual ring and that ring circumference was 194 geometrically circular. BAI was used as a standardization method to account for age- or size195 related growth trends, but maintained suppression and release events that may have resulted from 196 fire injury or climate (Biondi and Qeadan 2008, Speer 2010).

Vertical resin ducts in the xylem (Figure 2) were visually identified and measured using 198 ImageJ software (Rasband 2014). Three measurements were made in ImageJ for each annual 199 ring: a count of vertical resin ducts; the area $\left(\mathrm{mm}^{2}\right)$ of each resin duct; and the area $\left(\mathrm{mm}^{2}\right)$ of 200 each ring. From these measurements, we calculated resin duct production (\# ducts $\mathrm{y}^{-1}$ ), mean 201 resin duct size $\left(\mathrm{mm}^{2} \mathrm{y}^{-1}\right)$, and total resin duct area $\left(\mathrm{mm}^{2} \mathrm{y}^{-1}\right)$.

202 Since we measured multiple resin duct characteristics, preliminary correlation analysis 203 was conducted to reduce the number of defense response variables. Results indicated that resin 204 duct area had a strong positive relation to resin duct production $\left(r^{2}=0.62, p<0.01\right)$ and thus 205 resin duct production was excluded from further analysis and model considerations. 
209 after treatment. The coefficient of determination $\left(r^{2}\right)$ was calculated to assess how well the data

210 for each variable fit the linear model. Results from the relationships between growth and defense

211 before and after treatment determined the need for us to include tree as a random effect when

212 developing and conducting the generalized linear mixed modeling (explained in more detail

213 below).

214 To examine the influence of climate on growth and defense, we used the treeclim

215 package (Zang and Biondi 2014) in the statistical program $R$ (R Development Core Team 2015)

216 to determine which climate variables best explained variability in growth and defense. The

217 package performed correlation analysis by estimating Pearson's correlation coefficient $(r)$ and

218 confidence intervals based on bootstrapping methods with 1,000 iterations. Median correlation

219 coefficients were considered significant $(\alpha=0.05)$ if the absolute value surpassed half the

220 difference between the $97.5^{\text {th }}$ and $2.5^{\text {th }}$ quantile of the 1,000 estimates (percentile range method).

221 Climate variables included in our analysis were monthly temperature (minimum, maximum, and

222 mean), total monthly precipitation, and seasonal (spring, summer, winter, and fall) Palmer

223 Drought Severity Index (PDSI; Palmer 1965) for the current and previous year from 1994 to

2242013 (ten years prior to and ten years after burning treatments). Climate data were recorded from

225 the weather station at the Gainesville Regional Airport in Florida, located $16 \mathrm{~km}$ west of our

226 field site (NCDC 2014). We opted to use data from this single weather station due to its close

227 proximity to the study site and its full coverage over the 20 year study period.

228 The influence of the smoldering fire treatments and climate on longleaf pine growth and

229 defense measures were tested using generalized linear mixed modeling with the lme4 package

230 (Bates et al. 2015) in the program R (R Core Development Team 2015). This statistical approach 
231 was most appropriate given the nature of the data, which included a nested structure of annual

232 measurements within tree. All growth and defense models included a log link function in the

233 gamma distribution family to account for the non-normal distribution of the growth and defense

234 data. Covariates included previous year's growth (BAI) to control for temporal autocorrelation

235 and the specific climate parameters that had the best correlation with growth and defense. The no

236 fire treatment was selected as the reference category when assessing the effect of each treatment

237 on growth and defense. Akaike's information criterion (AIC) was used for model evaluation and

238 to assess the relative importance of treatment and climate on longleaf pine growth and defense.

239 All models were compared to a null model that included previous growth and random effect of

240 tree to determine if treatment, climate, or a combination of these factors best explained the

241 observed differences in growth and defense. Substantial differences in model fit were indicated

242 by a change in AIC values greater than 2 (Burnham and Anderson 2002).

243 Linear regression was used to examine the relationship of smoldering duration with

244 longleaf pine growth and defense. To meet statistical assumptions of linear regression,

245 measurements for lethal heating and smoldering duration were log-transformed. A box-cox test

246 determined that a square root transformation was most appropriate for BAI. To identify possible

247 variation in longleaf pine response during dry years, growth and defense measures were also

248 averaged for the three driest years during the ten years following treatment. The driest years were

249 selected separately for growth and defense based on the strongest correlations with seasonal

250 PDSI. Following treatment, the three driest years relative to growth were based off the lowest

251 values for average summer and fall PDSI and included 2006, 2007, and $2011(-3.39,-3.87$, and -

252 2.91, respectively). The three driest years relative to defense and based on average winter PDSI

253 were 2007, 2008, and $2011(-3.72,-2.90$, and -3.40 , respectively). 


\subsection{Within-tree and climate relationships}

In general, growth and defense measures were highly variable among trees, but pre-

257 treatment measures were positively correlated to post-treatment measures (Figure 3). Among all

258 sampled trees, average BAI over a ten year period varied from 1 to $30 \mathrm{~cm}^{2} \mathrm{y}^{-1}$, while resin duct

259 total area ranged from 0.01 to $1.32 \mathrm{~mm}^{2} \mathrm{y}^{-1}$. Longleaf pines with greater BAI and more resin duct

260 total area during the ten years prior to treatment consistently had greater values in the ten years

261 following treatment $\left(r^{2}=0.71, p<0.01\right.$ and $r^{2}=0.72, p<0.01$, respectively). Based on these

262 findings, we chose to include tree as a nested random factor in our generalized linear model

263 analysis to account for tree-based differences in growth and defense.

264 Longleaf pine BAI and resin duct area were related to several measures of climate,

265 throughout the 20 years analyzed (Table 1). BAI had a significant negative relationship with

266 current August temperature $(r=-0.49)$ and a positive relationship with current April precipitation

$267(r=0.42)$. Resin duct area exhibited a positive relationship with precipitation during November

268 of the previous year $(r=0.46)$ and no identifiable relationship with temperature. BAI and resin

269 duct size were correlated with monthly PDSI across seven months and four months, respectively.

270 Average PDSI during the summer months (June, July, August) and fall months (September,

271 October, November) was positively correlated with BAI $(r=0.40)$, while average PDSI during

272 the winter months (previous December - current February) was positively correlated with resin

273 duct area $(r=0.48)$.

274

2753.2 Treatment and climate effects

276 
278 years before treatment (Figure 4). Of all treatments, the root and stem burn showed the largest

279 decrease, where BAI decreased by $24 \%$. Despite this decrease, the model that included

280 treatment alone performed worse than the null model when predicting longleaf pine BAI (Table

281 2). The climate factor (summer and fall PDSI) was the top performing model followed by the

282 additive and interaction models between treatment and climate.

Resin ducts had less total area and were smaller in size following all treatments. The

284 greatest decrease occurred in the root and stem treatment, where area was reduced by $36 \%$ and

285 resin ducts were $27 \%$ smaller (Figure 5). Resin duct total area was best predicted by precipitation

286 from the previous November, and treatment alone did not outperform the null model (Table 2).

287 The second and third best model included the additive and interaction models between treatment

288 and precipitation from the previous November. The best model in predicting average resin duct

289 size included the interaction between treatment and November precipitation from the previous

290 year (Table 2), however, there was no substantial difference between the top model and the

291 second best model. Compared to the no fire control, all three smoldering fire treatments had a

292 negative impact on resin duct size. The interaction between treatment and precipitation had the

293 greatest effect on trees from the root and stem burn, which experienced the greatest reduction in

294 resin duct size when precipitation from the previous November was low.

295 Smoldering duration and lethal heating in the soil and at the stem base were not

296 significantly related to longleaf pine growth and defense. However, when specifically assessing

297 the three driest years relative to growth and defense post-treatment, smoldering duration had a

298 negative relationship with BAI $\left(p<0.0085 ; r^{2}=0.08\right.$; Figure 6a) and mean resin duct size $(p<$

$299 \quad 0.0003 ; r^{2}=0.17$; Figure 6b). 


\section{Discussion}

\subsection{Within-tree and climate factors}

Despite notable variation among trees, previous and subsequent growth and defense characteristics were strongly related regardless of treatment (Figures 4 \& 5). Longleaf pines that allocate proportionally more resources to growth and/or defense prior to treatment continued to similarly allocate resources after treatment. This result suggests that other factors such as microsite conditions or genotypic differences may influence growth and defense more than exposure to our fire treatments. Microsite differences may be associated with variability in the competitive environment that can influence the availability of light, water, and nutrients (Meldahl et al. 1999, Mitchell et al. 2006). Recent evidence indicates that allocation to growth and resin defense traits in pines are strongly heritable (Strom et al. 2002, Rosner and Hanrup 2004, Westbrook et al. 2015), suggesting a potential genetic contribution to the observed variation. Neither microsite nor genetic differences were measured as part of this study, but may explain substantial differences in future research.

The results from our climate and growth relationship analyses were consistent with previous studies on longleaf pine across multiple sites in the southeastern Coastal Plain (Meldahl et al. 1999, Henderson and Grissino-Mayer 2009). We found that current August temperature had a negative relationship with longleaf pine growth, consistent with the relationship found for growth in Texas and latewood growth in both Texas and South Carolina (Henderson and Grissino-Mayer 2009). Similar to our study, Henderson and Grissino-Mayer (2009) also found that longleaf pine growth in Florida was positively correlated with April precipitation and PDSI from July-November of the current year. In contrast to previous studies that found the relationship between temperature and growth to be the weakest among climate variables 
323 (Meldahl et al. 1999, Henderson and Grissino-Mayer 2009), we found temperature to have a

324 higher correlation with growth than precipitation and PDSI. One possible explanation for this

325 difference could be that longleaf pine growth at our site is becoming more limited by

326 temperature due to a stronger influence on potential evapotranspiration than precipitation.

327 However, our study investigated different timespans, years, and geographic regions than the

328 other two studies. Given increased warming over the past few decades in Florida, continued

329 research on growth and climate relationships is warranted.

330 We are aware of only a few studies that directly compared vertical resin duct properties

331 to climate variables. In eastern Germany, Wimmer and Grabner (1997) found Norway spruce

332 (Picea abies) resin duct density had a positive relationship with above average summer

333 temperature and a negative relationship to spring precipitation, both during the current year.

334 Furthermore, in the northern Rocky Mountains of the United States, Hood et al. (2015) found

335 ponderosa pine ( $P$. ponderosa) total resin duct area to have a positive relationship with a warme

336 and wetter July. Our study found that resin duct size in longleaf pines was positively correlate $r$

337 with precipitation during the previous November. Comparisons of our results with these studid

338 are difficult for many reasons including non-standardized measurements for resin duct

es

339 properties, different tree species, and varying ecological characteristics. For instance, the

340 aforementioned studies were from areas with more continental climates when compared to our

341 study site in north-central Florida. Continental climates have higher fluctuations in temperature

342 and precipitation, with over a third of the precipitation falling as snow, which considerably

343 differs from the climate found in our study site. More research exploring the relationship

344 between climate and tree defense is needed because tree defense has been shown to be an 
346 important factor in reducing pine mortality (Kane et al. 2010, Ferrenberg et al. 2014, Gaylord et

347 al. 2015, Hood et al. 2015), and defense-climate relationships may shift with increased

348 temperatures and altered climatic patterns associated with climate change.

We observed decreases in mean longleaf pine growth and defense over the 20 years examined independent of treatment effects. These trends may reflect broader climate changes in

351 the region, as temperature increased by $0.06^{\circ} \mathrm{C}$ and precipitation decreased by $0.46 \mathrm{~cm}$ over

352 study period. However, changes in temperature and precipitation were not statistically significant

$353(p>0.6)$. Alternatively, the continued growth of adjacent trees may have increased the

354 competitive load, influencing growth in subject trees over the course of the twenty years

355 examined (Das 2012).

356

\subsection{Treatment and climate effects}

Our results indicate that longleaf pine growth was relatively resistant to the effects of smoldering fire ten years following treatment, as previous growth, variability among trees, and climate factors explained greater amounts of variation than treatment when predicting basal area

361 increment in the mixed models. We found these results to be somewhat surprising considering

362 that Varner et al. (2009) found that the duration of smoldering duff temperatures were strongly

363 and negatively related to short-term ( $\mathrm{ca} .4$ months post-treatment) root non-structural

364 carbohydrate concentrations, and slightly related to latewood growth one year after treatment.

365 We anticipated that the loss of roots and corresponding declines in root carbohydrates might

366 cause further reductions in radial growth in subsequent years. Although treatment was not

367 informative in predicting post-fire growth, there was a significant relationship between increased

368 smoldering duration and reduced growth during the three driest years following treatment. It is 
369 possible that smoldering duration better captures the intensity of each experimental fire more 370 than treatment.

Previous research has shown that long-duration soil heating and duff consumption can

372 increase tree stress and mortality (Swezy and Agee 1991, Stephens and Finney 2002, Varner et

373 al. 2007, O'Brien et al. 2010). However, scorching that caused crown and bole damage are also

374 important factors contributing to tree mortality, and our study was specifically interested in the

375 effects of smoldering fire only and intentionally omitted scorching as a part of the treatments. It

376 is important to note that the interaction of different fire effects contributing to tree damage could

377 have stronger influences on tree growth than smoldering fire alone.

Resin duct total area was also generally resistant to the effects of the smoldering fire

379 treatment. However, the results revealed that resin duct size was negatively impacted by the

380 treatment. Furthermore, the interaction of lower precipitation during the previous November with

381 smoldering treatment further reduced the size of longleaf pine resin ducts. This may indicate that

382 smoldering treatments could negatively impact longleaf pine defense capabilities, if proceeded

383 by dry conditions and reduced precipitation.

384 We anticipated that duff burning treatments could have increased vertical resin duct area 385 due to an induced response following burning as found by Hood et al. (2015) and similar to 386 observations of increased resin flow from other studies (Lombardero et al. 2006, Perrakis and 387 Agee 2006). Conversely, short-term constitutive resin volume in September has been shown to 388 decrease with higher crown scorching (Wallin et al. 2003). While our results suggest that resin 389 duct size was negatively impacted by the smoldering fire treatments, it is difficult to directly 390 compare our results to other studies because we isolated smoldering fire behavior. Hood et al. 391 (2015) found that a low intensity and high frequency fire regime increased total resin duct area, 
392 while Wallin et al. (2003) found that high intensity fire resulting in greater crown scorch reduced

393 resin duct defenses (i.e. resin volume). It is possible that our smoldering fire treatments, which

394 intentionally omitted crown scorch, did not create conditions to independently promote or

395 dampen resin duct development. These studies reflect notable differences in how tree defense

396 responded to fire behavior, highlighting the need for more information on the mechanisms

397 responsible for fire-induced changes in resin duct defenses.

While longleaf pine growth and defense were generally resistant to smoldering

399 treatments, this effect was contingent upon the post-fire climatic conditions. We detected a

400 decrease in both growth and defense measures in the driest years following treatment. In fact,

401 one of the dry years analyzed for both growth and defense was 8 years following treatment

402 (2011); suggesting that the interaction of smoldering fire and dry climate conditions may have

403 longer-term effects on longleaf pine growth and defense. This is congruent with other research

404 that has found strong correlations between abrupt growth declines in the past, typically reflective

405 of drought and climate fluctuations, and increased probability of mortality, warranting the need

406 to examine cumulative growth trends over extended time periods (Das 2008, Pederson 1998). As

407 a result, smoldering fire may increase the probability of longleaf pine mortality for many years,

408 especially in drier years following treatment. This extended effect may help explain the delayed

409 mortality phenomenon reported for longleaf pine (Varner et al. 2007) and many western conifers

410 following the reintroduction of fire (Agee 2003, Thies et al. 2006, Hood 2010, Nesmith et al.

$4112015)$. 

treatments over ten years. The exception to this pattern was during drier years following treatments when growth was negatively impacted by smoldering duration. Resin duct size was

417 negatively impacted by the treatment, and the effects were worsened when precipitation was

418 lower during the previous November. These results indicate that smoldering fire after a

419 prolonged period of fire exclusion will not have substantial longer-term negative impacts to 420 longleaf pine vigor unless climate conditions following treatments are consistently drier. The

421 most recent climate projections for Florida include warmer temperatures with more precipitation

422 (Van Oldenborgh et al. 2013), complicating our ability to speculate how climate change may

423 influence long-term resistance following smoldering fire. However, we also found that the

424 negative impacts of smoldering on growth and defense during dry years was related to the 425 duration of smoldering associated with treatments. Managers may decrease these negative 426 impacts by burning during wetter and cooler conditions to reduce the duration of smoldering and 427 its consequences (Varner et al. 2007). The long-term recovery we observed in longleaf pine 428 holds promise for restoration efforts in the region where concerns over potential post-fire 429 mortality impede the application and use of fire (Hiers et al. 2003). Determining thresholds for 430 fire injury, including the compounding effects of crown scorch, will be important steps toward 431 restoring fire-excluded longleaf pine ecosystems.

433 Acknowledgements 
437 Joint Fire Science Program under projects JFSP 10-1-08-5 and 15-1-05-5. Financial support for 438 AWS and NEZ-K was provided by a grant from the USDA Forest Service PSW Research 439 Station. JMK and JMV were partially supported by their current institutions. J. Kreye and W. 440 Reed collected core samples in 2013. S. Chandler and S. Mehlman assisted in processing tree 441 cores and preliminary statistical analysis.

442

$443 \quad$ References

444 Agee, J.K. 1996. Fire Ecology of Pacific Northwest forests. Island Press, Washington, D.C. 445

446 Agee, J.K. 2003. Monitoring postfire tree mortality in mixed-conifer forests of Crater Lake, 447 Oregon, USA. Natural Areas Journal 23, 114-120.

448

449 Agee, J.K., Skinner, C.N. 2005. Basic principles of forest fuel reduction treatments. Forest 450 Ecology and Management 211, 83-96.

451

452 Anderson, D.R., Burnham, K.P. 2002. Avoiding pitfalls when using information-theoretic 453 methods. The Journal of Wildlife Management 66, 912-918.

454

455 Bates, D., Maechler, M., Bolker, B., Walker, S. 2015. Fitting linear mixed-effects models using 456 lme4. Journal of Statistical Software 67, 1-48.

457

458 Biondi, F., Qeadan, F. 2008. A theory-driven approach to tree-ring standardization: defining the 459 biological trend from espected basal area increment. Tree-Ring Research 64, 81-96. 
461 Brown, R.T., Agee, J.K., Franklin, J.F. 2004. Forest Restoration and Fire: Principles in the 462 context of place. Conservation Biology 18, 903-912.

463

464 Das, A.J., Battles, J.J., Stephensen, N.L., van Mantgem, P.J. 2007. The relationship between tree 465 growth patterns and likelihood of mortality: a study of two tree species in the Sierra Nevada. 466 Canadian Journal of Forest Research 37, 580-597.

467

468 Das, A.J. 2012. The effect of size and competition on tree growth rate in old-growth coniferous 469 forests. Canadian Journal of Forest Research 42, 1983-1995.

470

471 D'Amato, A.W., Bradford, J.B., Fraver, S., Palik, B.J. 2013. Effects of thinning on drought 472 vulnerability and climate response in north temperate forest ecosystems. Ecological Applications $473 \quad 23,1735-1742$.

474

475 Ferrenberg, S., Kane, J.M., Mitton, J.B. 2013. Resin duct characteristics associated with tree 476 resistance to bark beetles across lodgepole and limber pines. Oecologia 174, 1283-1292.

477

478 Frost, C.C. 2006. History and future of the longleaf pine ecosystem. In: Jose, S., Jokela, E.J., 479 Miller, D.L. (Eds.) The Longleaf Pine Ecosystem: Ecology, Silviculture, and Restoration. 480 Springer, New York, NY. Pp. 9-42. 
482 Gaylord, M.L. , Kolb, T.E., McDowell, N.G. 2015. Mechanisms of piñon pine mortality after 483 severe drought: a retrospective study of mature trees. Tree Physiology 35, 806-816

484

485 Gilliam, F.S., Platt, W.J. 1999. Effects of long-term fire exclusion on tree species composition 486 and stand structure in an old-growth Pinus palustris (Longleaf pine) forest. Plant Ecology 140

$487 \quad 15-26$.

488

489 Grissino-Mayer, H.D. 2001. Evaluating cross-dating accuracy: A manual and tutorial for the 490 computer program COFECHA. Tree Ring Society 57, 205-221.

491

492 Gunderson, L.H. 2000. Ecological resilience - In theory and application. Annual Review of 493 Ecology and Systematics 31, 425-439.

494

495 Henderson, J.P., Grissino-Mayer, H.D. 2009. Climate-tree growth relationships of longleaf pine 496 (Pinus palustris Mill.) in the southeastern Coastal Plain, USA. Dendrochronologia 27, 31-43.

498 Hiers, J. K., Laine, S.C., Bachant, J.J., Furman, J.H., Greene, W.W., Compton, V. 2003. Simple 499 spatial modeling tool for prioritizing prescribed burning activities at the landscape scale.

500 Conservation Biology 17, 1571-1578.

501

502 Holling, C.S. 1973. Resilience and stability of ecological systems. Annual Review of Ecology 503 and Systematics 4, 1-23.

504 
505 Hood, S.M. 2010. Mitigating old tree mortality in long-unburned, fire-dependent forests: a 506 synthesis. General Technical Report RMRS-GTR-238. Fort Collins, Colorado: U.S. Department 507 of Agriculture, Forest Service, Rocky Mountain Research Station.

508

509 Hood, S.M., Sala, A., Heyerdahl, E.K., Boutin, M. 2015. Low-severity fire increasestrees 510 defense against bark beetle attacks. Ecology 96, 1846-1855.

511

512 Kane, J.M., Kolb, T.E. 2010. Importance of resin ducts in reducing ponderosa pine mortality 513 from bark beetle attack. Oecologia 164, 601-609.

514

515 Keane, R.E., Ryan, K.C., Veblen, T.T., Allen, C.D., Logan, J., Hawkes, B. 2002. Cascading 516 effects of fire exclusion in Rocky Mountain ecosystems: A literature review. USDA Forest 517 Service, Rocky Mountain Research Station General Technical Report RMRS-GTR-91. 518

519 Lombardero, M.J., Ayres, M.P., Ayres, B.D. 2006. Effects of fire and mechanical wounding on 520 Pinus resinosa resin defenses, beetle attacks, and pathogens. Forest Ecology and Management $521225,349-358$.

522

523 Lloret, F., Keeling, E.G., Sala, A. 2011. Components of tree resilience: effects of successive low524 growth episodes in old ponderosa pine forests. Oikos 120, 1909-1920. 525

526 Lutes, D.C. 2013. FOFEM 6.0 user guide. Online document. URL: www.firelab.org/ 527 ScienceApps_Files/downloads/FOFEM/FOFEM6_Help.pdf. Accessed 24 March 2014. 
529 Meldahl, R.S., Pederson, N., Kush, J.S., Varner, J.M.1999. Dendrochronological investigations

530 of climate and competitive effects on longleaf pine growth. In: Wimmer, R., Vetter, R.E. (Eds.),

531 Tree Ring Analysis: Biological, Methodological and Environmental Aspects. CABI Publishing,

532 Oxon, United Kingdom, pp. 265-285.

533

534 Millar, C.I., Stephenson, N.L., Stephens, S.L. 2007. Climate change and forests of the future:

535 managing in the face of uncertainty. Ecological Applications 17, 2145-2151.

536

537 Mitchell, R.J., Hiers, J.K., O'Brien, J.J., Jack, S.B., Engstrom, R.T. 2006. Silviculture that

538 sustains: The nexus between silviculture, frequent prescribed fire, and conservation of

539 biodiversity in longleaf pine forests of the southeastern United States. Canadian Journal of

$540 \quad$ Forest Research 36, 2724-2736.

541

542 National Climate Database Center (NCDC). 2014. Available at http://www.ncdc.noaa.gov/.

543 Accessed 14 October 2014.

544

545 Nesmith, J.C.B., Das, A.J., O'Hara, K.L., van Mantgem, P.J. 2015. The influence of prefire tree 546 growth and crown condition on postfire mortality of sugar pine following prescribed fire in

547 Sequoia National Park. Canadian Journal of Forest Research 45, 910-919. 
549 Noss, R.F., LaRoe, E.T., Scott, J.M. 1995. Endangered ecosystems of the United States: A

550 preliminary assessment of loss and degradation. US Department of the Interior National

551 Biological Service, Biological Report 28. US Dept. of the Interior (Washington, D.C).

552

553 O’Brien, J.J., Hiers, J.K., Mitchell, R.J., Varner, J.M., Mordecai, K. 2010. Acute physiological 554 stress and mortality following fire in a long-unburned longleaf pine ecosystem. Fire Ecology 6, $555 \quad 1-12$.

556

557 Palmer, W.C. 1965. Meteorological drought. Research paper no. 45, U.S. Department of 558 Commerce, Washington, D.C.

559

560 Perrakis, D.B., Agee, J.K. 2006. Seasonal fire effects on mixed-conifer forest structure and 561 ponderosa pine resin properties. Canadian Journal of Forest Research 36, 238-254.

562

563 Platt, W.J. 1999. Southeastern pine savannas. In: Anderson, R.C., Fralish, J.S, Baskin, J.M.

564 (Eds.), Savannas, Barrens, and Rock Outcrop Plant Communities of North America. Cambridge 565 University Press, Cambridge, United Kingdom, pp. 23-51.

566

567 R Development Core Team. 2015. R: A language and environment for statistical computing. R 568 Foundation for Statistical Computing, Vienna, Austria.

569

570 Rasband, W.S. 2014. ImageJ, U. S. National Institutes of Health, Bethesda, Maryland. Available 571 from: http://imagej.nih.gov/ij. 
573 Readle, E.L. 1990. Soil survey of Putnam County Area Florida. USDA Soil Conservation

574 Service and Florida Agricultural Experiment Station, Gainesville, FL.

575

576 Regent Instruments Inc. 2009. WinDendro. Regent Instruments, Quebec, Canada.

577

578 Rigling, A., Brühlhart, H., Bräker, O.U., Forster, T., Schweingruber, F.H. 2003. Effects of

579 irrigation on diameter growth and vertical resin duct production in Pinus sylvestris L. on dry sites

580 in the central Alps, Switzerland. Forest Ecology and Management 175, 285-296.

581

582 Rosner, S., Hannrup, B. 2004. Resin canal traits relevant for constitutive resistance of Norway

583 spruce against bark beetles: environmental and genetic variability. Forest Ecology and

584 Management 200, 77-87.

585

586 Ryan, K.C. and Frandsen, W.H. 1991. Basal injury from smoldering fires in mature Pinus

587 ponderosa Laws. International Journal of Wildland Fire 1, 107-18.

588

589 Ryan, K.C., Knapp, E.E., Varner, J.M. 2013. Prescribed fire in North American forests and 590 woodlands: history, current practice, and challenges. Frontiers in Ecology and the Environment 591 11, e15-e24.

592

593 Stambaugh, M.C., Guyette, R.P., Marschall, J.M. 2011. Longleaf pine (Pinus palustris Mill.) fire 594 scars reveal new details of a frequent fire regime. Journal of Vegetation Science 22, 1094-1104. 
596 Speer, J.H. 2010. Fundamentals of tree-ring research. The University of Arizona Press, Tucson, 597 Arizona.

598

599 Stephens, S.L., Finney, M.A. 2002. Prescribed fire mortality of Sierra Nevada mixed conifer tree 600 species: Effects of crown damage and forest floor combustion. Forest Ecology and Management $601 \quad 162,261-271$.

602

603 Strom, B.L., Goyer, R.A., Ingram Jr., L.L., Boyd, G.D.L., Lott, L.H. 2002. Oleoresin

604 characteristics of progeny of loblolly pines that escaped attack by the southern pine beetle.

605 Forest Ecology and Management 158, 169-178.

606

607 Swezy, D.M., Agee, J.K. 1991. Prescribed-fire effects on fine-root and tree mortality in old-

608 growth ponderosa pine. Canadian Journal of Forest Research 21, 626-634.

609

610 Thies, W.G., Westlind, D.J., Loewen, M., Brenner, G. 2006. Prediction of delayed mortality of

611 fire-damaged ponderosa pine following prescribed fires in eastern Oregon, USA. International

612 Journal of Wildland Fire 15, 19-29.

613

614 Thomas, Z., Waring, K.M. 2015. Enhancing resiliency and restoring ecological attributes in 615 second-growth ponderosa pine stands in northern New Mexico, USA. Forest Science 61, 93-104. 
617 Van Lear, D.H., Carroll, W.D., Kapeluck, P.R., Johnson, R. 2005. History and restoration of the 618 longleaf pine-grassland ecosystem: Implications for species at risk. Forest Ecology and 619 Management 211, 150-165.

620

621 van Mantgem, P.J., Nesmith, J.C.B., Keifer, M.B., Knapp, E.E., Flint, A., Flint, L. 2013.

622 Climatic stress increases forest fire severity across the western United States. Ecology Letters 16, $623 \quad 1151-1156$.

624

625 Van Oldenborgh G.J., Collins M., Arblaster J., Christensen J.H., Marotzke J., Power S.B., et al. 626 2013. Annex I: atlas of global and regional climate projections. In: Stocker TF, Qin D, Plattner 627 G.-K., Tignor M, Allen SK, Boschung J, et al., editors. Climate Change 2013: The Physical 628 Science Basis Contribution of Working Group I to the Fifth Assessment Report of the 629 Intergovernmental Panel on Climate Change. Cambridge, United Kingdom and New York, 630 (NY): Cambridge University Press. Pp. 1311-1393.

631

632 Varner, J.M., Gordon, D.R., Putz, F.E., Hiers, J.K. 2005. Restoring fire to long-unburned Pinus 633 palustris ecosystems: Novel fire effects and consequences for long-unburned ecosystems.

634 Restoration Ecology 13, 536 -544.

635

636 Varner, J.M., Hiers, J.K., Ottmar, R.D., Gordon, D.R., Putz, F.E., Wade, D.D. 2007. Overstory 637 tree mortality resulting from re-introducing fire to long-unburned longleaf pine ecosystems: The 638 importance of duff moisture. Canadian Journal of Forest Research 37, 1349-1358. 639 
$642 \quad 2467-2474$.

643

644 Webster, J.R., Waide, J.B., Patten, B.C. 1975. Nutrient recycling and the stability of ecosystems.

645 In: Howell, F. (ed.), Mineral Cycling in Southeastern Ecosystems, ERDA Symposium, Series

646 Conference 740513, Augusta, Georgia, pp. 1-27.

Varner, J.M., Putz, F.E., O'Brien, J.J., Mitchell, R.J., Hiers, J.K., Gordon, D.R. 2009. Post-fire tree stress and growth following smoldering duff fires. Forest Ecology and Management 258,
648

649

650

651

652

653

654

655

656

657

658

659

660

661

662

47

Westbrook, J.W., Walker, A.R., Neves, L.G., Munoz, P., Resende, M.F.R., Neale, D.B., Wegrzyn, J.L., Huber, D.A., Kirst, M., Davis, J.M., Peter, G.F. 2015. Discovering candidate genes that regulate resin canal number in Pinus taeda stems by integrating genetic analysis across environments, ages, and populations. New Phytologist 205, 627-641.

Wallin, K.F., Kolb, T.E., Skov, K.R., Wagner, M.R. 2003. Effects of crwon scorch on ponderosa pine resistance to bark beetles in northern Arizona. Environmental Entomology 32, 652-661.

Wimmer, R., Grabner, M. 1997. Effects of climate on vericle resin duct density and radial growth of Norway spruce [Picea abies (L.) Karst.]. Trees 11, 271-276.

Wu, H., Hu, Z. 1997. Comparative anatomy of resin ducts of the Pinaceae. Trees 11, 135-43.

Zang, C., Biondi, F. 2015. Treeclim: an R package for the numerical calibration of proxy-climate relationships. Ecography 38, 431-436. 


\section{List of Figures}

665 Figure 1. Map of study area, located at the Ordway-Swisher Biological Station near Melrose, Florida in 666 Putnam County (N 29840 / W 81874). The inset map displays the natural range of longleaf pine

667 ecosystems in the southeastern United States and the airplane symbol shows the location of the weather 668 station at the Gainesville Regional Airport.

669

670 Figure 2. A photograph of a magnified tree core with vertical resin ducts and year of treatment (2003)

671 distinguished with arrows.

672

673 Figure 3. The relationship of previous longleaf pine growth and defense (1994-2003) on subsequent 674 growth and defense (2004-2013). The coefficient of determination $\left(r^{2}\right)$ for basal area increment was 0.71

675 (A), and the $r^{2}$ for resin duct area was 0.72 (B). The area shaded gray represents the $95 \%$ confidence 676 interval for each linear model

677

678 Figure 4. Mean basal area increment $\left(\mathrm{cm}^{2} \mathrm{y}^{-1}\right)$ for each smoldering treatment from 1994 (ten years prior to 679 treatment) to 2013 (ten years after treatment). The vertical solid line represents the 2003 treatments, which 680 included surface fire (SF), no fire (NF), root burn (R), root and stem burn (RS), and stem burn (S). There 681 was no significant difference in growth between any of the treatments in the ten years following the 682 smoldering fire treatments.

683

684 Figure 5. (A) Resin duct total area and (B) mean resin duct size $\left(\mathrm{mm}^{2} \mathrm{y}^{-1}\right)$ for each treatment from 1994 685 (ten years prior to treatments) to 2013 (ten years after treatments). The vertical solid line represents the 6862003 treatments, which included surface fire (SF), no fire (NF), root burn (R), root and stem burn (RS), 
and stem burn (S). Resin duct size from trees in the stem burn were significantly smaller than the no fire control in the years following treatment.

Figure 6. The relationship between smoldering duration and (A) dry year growth, measured as basal area increment (BAI) and (B) defense, measured as mean resin duct size. A log transformation was applied to the unit of smoldering time and a square root transformation was applied to BAI to meet statistical assumptions of linear regression.

694

\section{Tables}

696 Table 1. Significant correlations between climatic factors (temperature, precipitation, and the Palmer 697 Drought-Severity Index, PDSI) and longleaf pine growth and defense characteristics. For PDSI, the 698 summer and fall average included the months June-November; the winter average included the previous 699 December, and the current January-February.

\begin{tabular}{ccccc}
\hline Variable & Month/Season & $\begin{array}{c}\text { Correlation } \\
\text { Coefficient }\end{array}$ & \multicolumn{2}{c}{ Confidence Interval } \\
\hline Basal area increment $\left(\mathbf{c m}^{\mathbf{2}} \mathbf{y}^{\mathbf{- 1}}\right)$ & Lugust & -0.49 & -0.71 & -0.13 \\
Temperature & April & 0.42 & 0.13 & 0.71 \\
Precipitation & $\begin{array}{c}\text { Fall and Summer } \\
\text { Average }\end{array}$ & 0.40 & 0.11 & 0.65 \\
PDSI & Previous November & 0.48 & 0.15 & 0.75 \\
Resin duct area $\left(\mathbf{m m}^{\mathbf{2}} \mathbf{y}^{\mathbf{- 1}}\right)$ & Winter Average & 0.46 & 0.23 & 0.68 \\
Precipitation & & & & \\
PDSI & &
\end{tabular}

702 Table 2. Longleaf pine growth (BAI, $\mathrm{cm}^{2} \mathrm{y}^{-1}$ ) and defense (resin duct total area and mean size, $\mathrm{mm}^{2} \mathrm{y}^{-1}$ ) 703 generalized linear mixed model results. Growth was best predicted by summer and fall PDSI (Palmer 704 drought severity index) and defense was best predicted by smoldering fire treatment and precipitation 705 during the previous November. The null model included Tree as a nested random effect and previous 
706 year's growth (BAI) as a covariate. K represents the relative number of parameters, and Akaike's

707 information criterion (AIC) was used to select the best model.

708

\begin{tabular}{|c|c|c|c|c|c|}
\hline Models & $\mathbf{K}$ & AIC & $\Delta$ AIC & $\begin{array}{c}\text { AIC } \\
\text { weights }\end{array}$ & $\begin{array}{c}\text { Log } \\
\text { Liklihood } \\
\end{array}$ \\
\hline \multicolumn{6}{|l|}{ Growth: Basal Area Increment } \\
\hline PDSI & 5 & 4852.50 & 0.0 & 0.71 & -2421.25 \\
\hline Treatment + PDSI & 9 & 4854.32 & 1.82 & 0.28 & -2418.16 \\
\hline Treatment $*$ PDSI & 13 & 4861.56 & 9.06 & 0.01 & -2417.78 \\
\hline Null (Previous growth + Tree) & 4 & 5043.70 & 191.20 & 0.00 & -2517.85 \\
\hline Treatment & 8 & 5045.48 & 192.98 & 0.00 & -2514.74 \\
\hline \multicolumn{6}{|l|}{ Defense: Resin Duct Total Area } \\
\hline Precipitation & 5 & -1898.17 & 0.00 & 0.88 & 954.09 \\
\hline Treatment + Precipitation & 9 & -1893.97 & 4.20 & 0.11 & 955.99 \\
\hline Treatment* Precipitation & 13 & -1888.72 & 9.45 & 0.01 & 957.36 \\
\hline Null (Previous growth + Tree) & 4 & -1887.97 & 10.21 & 0.01 & 947.98 \\
\hline Treatment & 8 & -1883.63 & 14.55 & 0.00 & 949.81 \\
\hline \multicolumn{6}{|l|}{ Defense: Resin Duct Size } \\
\hline Treatment $*$ Precipitation & 13 & -4668.60 & 0.00 & 0.48 & 2347.30 \\
\hline Treatment + Precipitation & 9 & -4668.45 & 0.14 & 0.45 & 2343.23 \\
\hline Precipitation & 5 & -4664.56 & 4.04 & 0.06 & 2337.28 \\
\hline Treatment & 8 & -4657.12 & 11.48 & 0.00 & 2336.56 \\
\hline Null (Previous growth + Tree) & 4 & -4653.21 & 15.39 & 0.00 & 2330.60 \\
\hline
\end{tabular}

709

710 


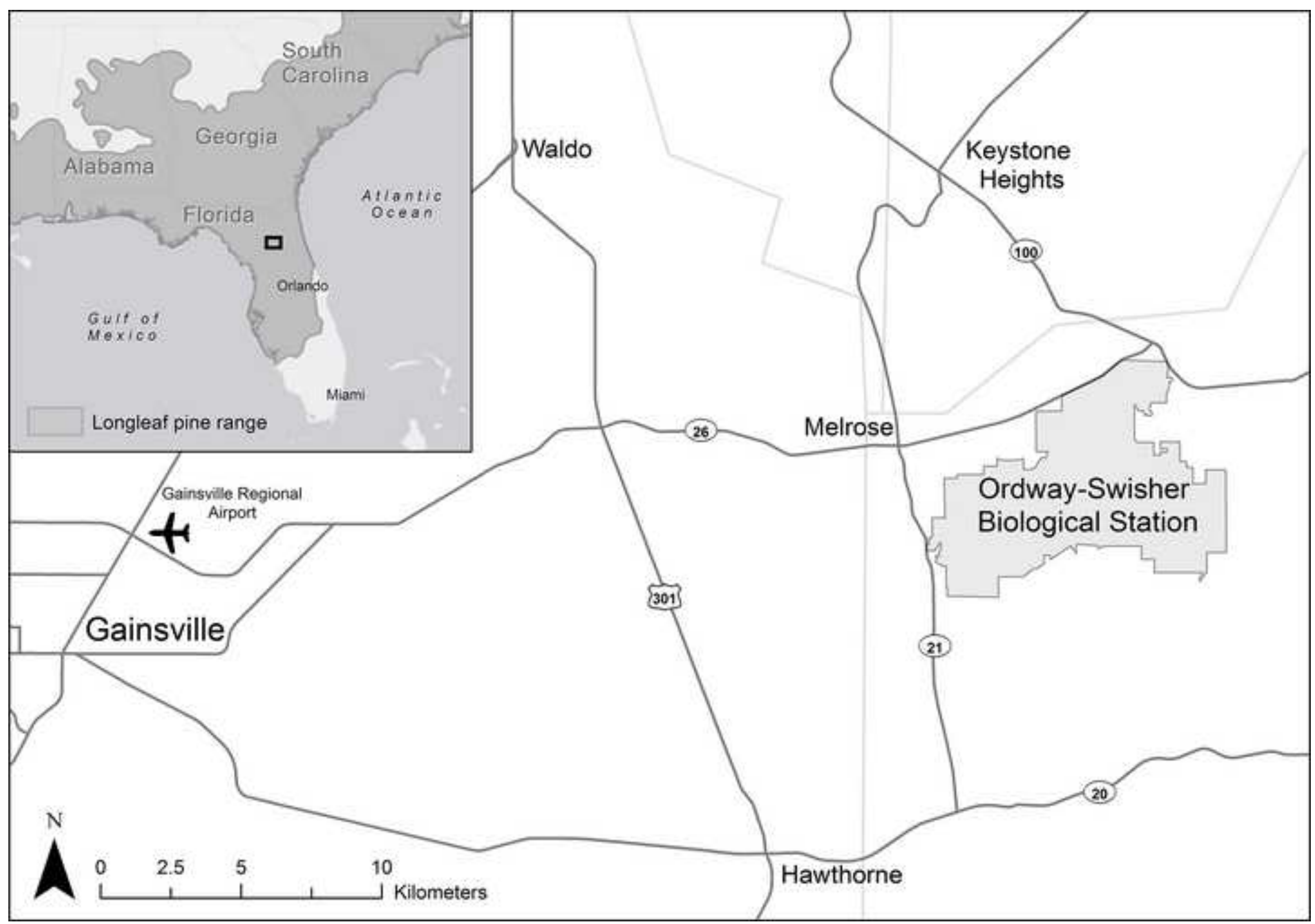




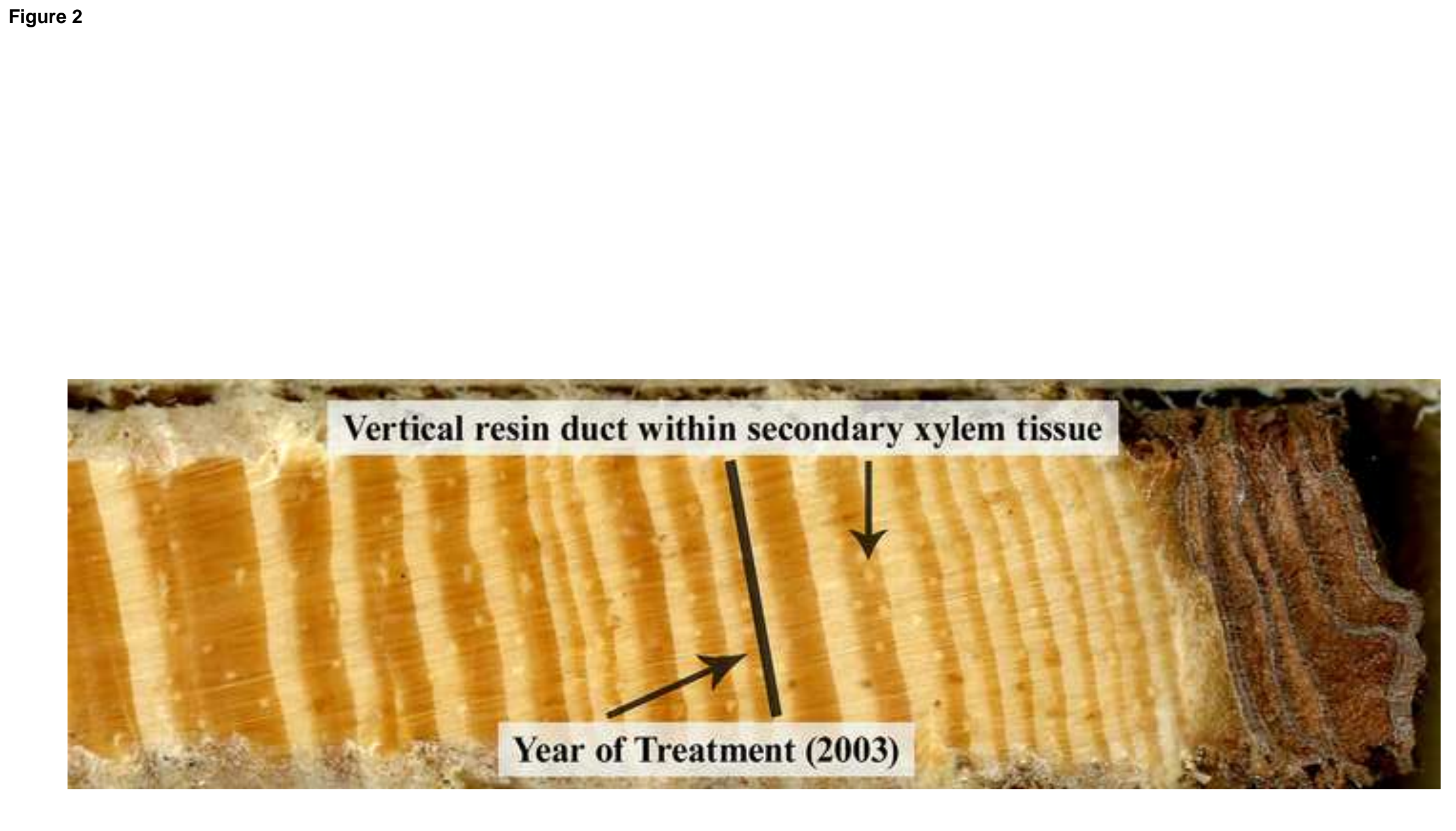

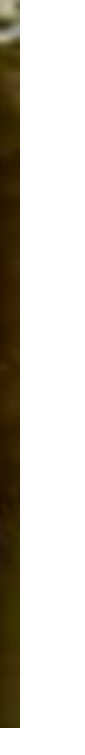

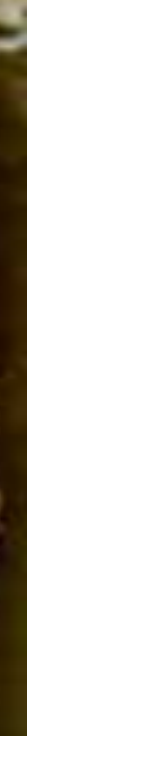



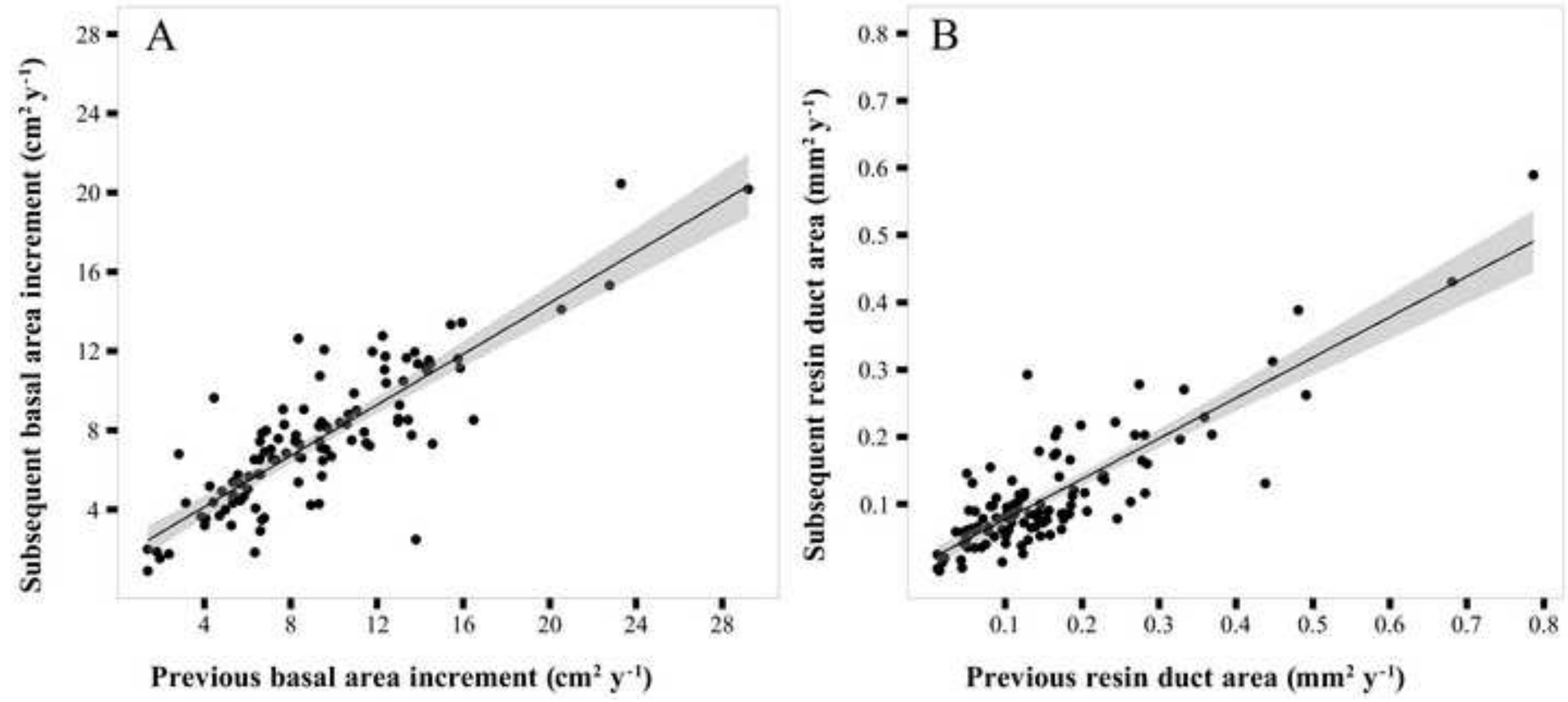


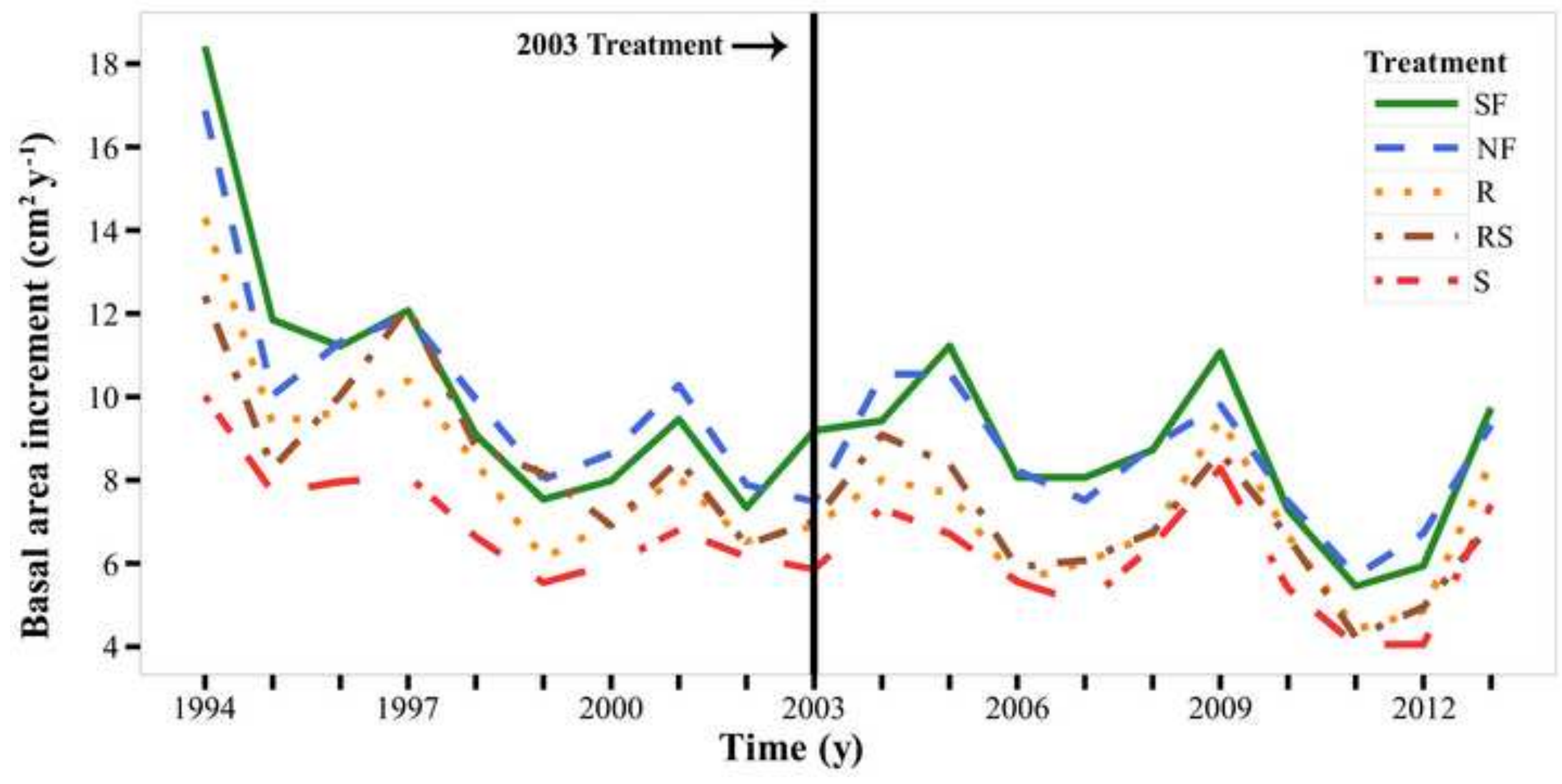



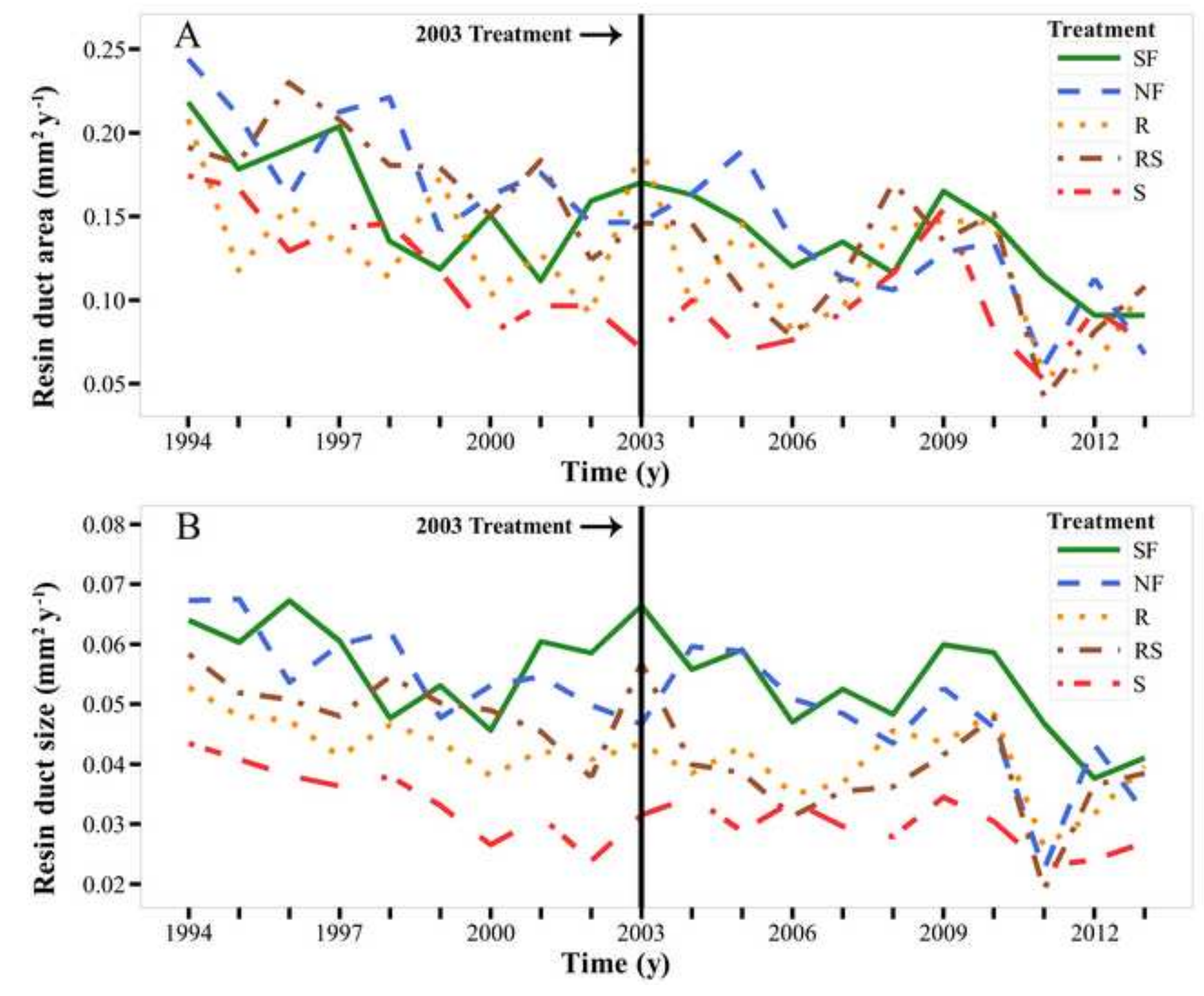

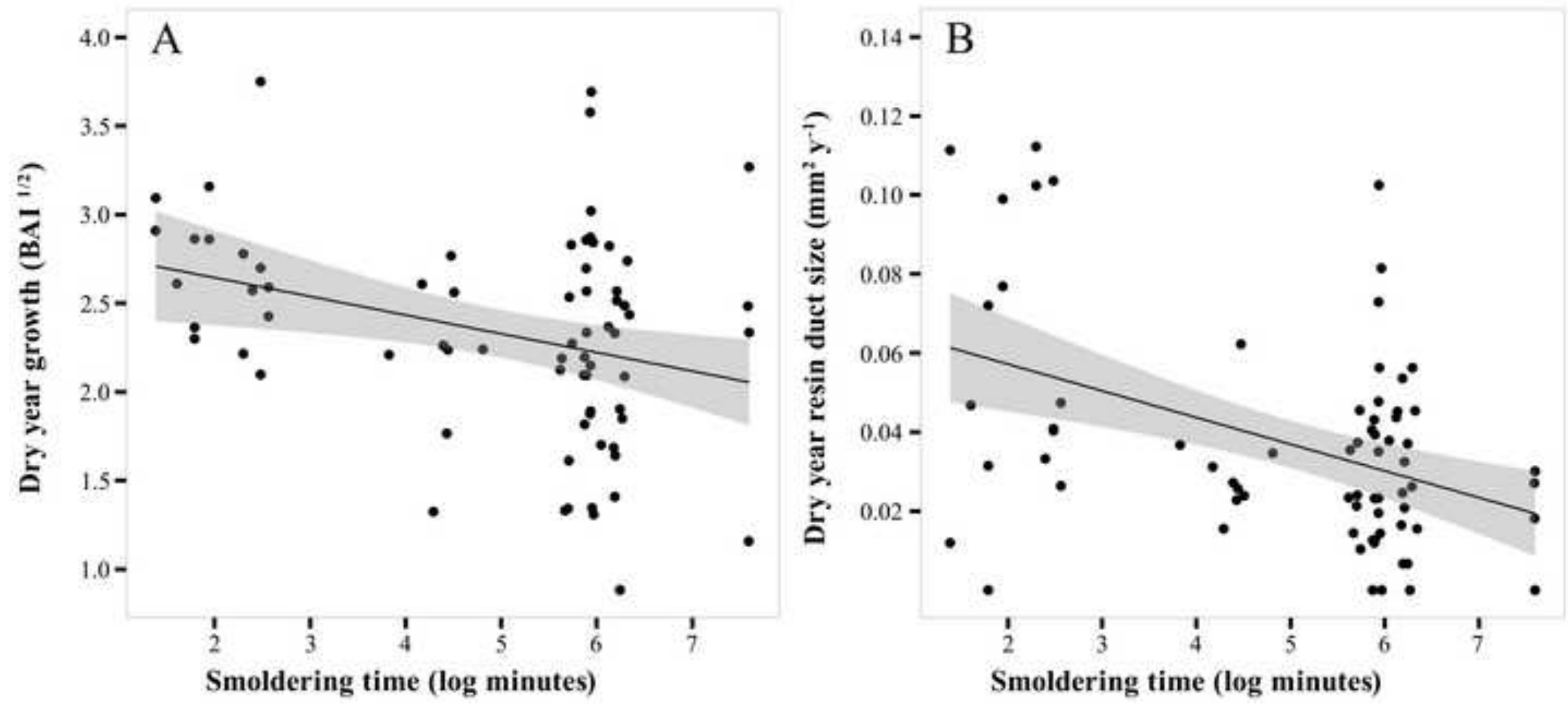